\title{
Antioxidant Potential of Kersen Leaves (Muntingia Calabura L.) Leaves to Increase Endogenous Glutathione Peroxidase (GPx) Enzymes in Diabetic Rats
}

\author{
Ratna Indriawati*, Anatyo Nizar \\ Faculty of Medicine and Health Sciences, Muhammadiyah Yogyakarta University, Bantul, \\ Yogyakarta, Indonesia
}

\begin{abstract}
The prevalence of diabetes mellitus (DM) is increasing. DM can cause an imbalance between protective antioxidants and increased production of free radicals. One such antioxidant is the endogenous enzyme glutathione peroxidase (GPx). Kersen (Muntingia calabura L.) contains flavonoids which show antioxidant activity. The purpose of this study was to examine the potential antioxidant of Kersen Leaves (Muntingia Calabura L.) leaves to GPx Enzymes in Diabetic Rats. This research is included in an experimental study with a post-test design only with control category design. The subjects of this study were 36 male rats. The measure of GDP levels using the GOD-PAP enzymatic method, while GPx uses the UV method. Data were analyzed using paired-t-test and OneWay ANOVA test. Statistical test results with paired $t$ test showed significant differences in GDP levels before and after treatment $(p=0.0001)$. In the OneWay ANOVA test there was a average different GPx levels in each category $(\mathrm{p}=0.0001)$. The most effective steeping increases the GPx level is a dose of $750 \mathrm{mg} /$ 200 gr BW.
\end{abstract}

Keywords. Kersen leaves, Muntingia Calabura L, Diabetes Mellitus, Glutathione Peroxidase, Oxidative stress.

\section{Introduction}

Diabetes mellitus (DM) is one of the public health problems. According to the results of DM epidemiological studies, Indonesian population aged over 15 years shows a prevalence of $1.5-2.3 \%[1,2]$. Diabetes Mellitus is divided into several types, namely Type I Diabetes Mellitus, Type II Diabetes Mellitus, Gestational Type Diabetes Mellitus, and Other Type Diabetes Mellitus. The most common type of Diabetes Mellitus is Type 2 Diabetes Mellitus. Type 2 Diabetes Mellitus (DM Type 2) is a metabolic disorder characterized by an increase

* Corresponding author: r_indriawatiwibowo@yahoo.com 
in blood sugar due to decreased insulin secretion by pancreatic beta cells and impaired insulin function (insulin resistance) [3-6].

An increase in blood sugar or hyperglycemia results in glucose auto-oxidation, protein glycation, and activation of the polyol metabolic pathway which further acceleracers the formation of reactive oxygen compounds. Formation of reactive oxygen compounds can increase lipid, DNA, and protein modification in various tissues. Molecular modification in these tissues results in an imbalance between protective antioxidants (antioxidant defenses) and increased production of free radicals. This is the beginning of oxidative damage known as oxidative stress. In Diabetes Mellitus, antioxidant defenses and cellular repair systems will be stimulated in response to the challenges of oxidative stress. Defense status includes the antioxidant enzyme endogenous glutathione peroxidase (GPx), superoxide dismutase (SOD), vitamin $C$ and catalase. Other alternatives are needed to reduce the oxidative damage [7-9].

Kersen leaves (Muntingia calabura L.) are one of the natural resources that have the potential to be used. Qualitatively it is known that the dominant compound in kersen leaves is flavonoids which show antioxidant activity. Flavonoid compounds are thought to be beneficial in food because they contain strong antioxidants. One of the antioxidants that the body has is peroxide. Peroxide levels will increase according to increased oxidative stress, one of which is hyperglycemia. Peroxidase activity in the liver will increase and the level of glutathione as an endogenous antioxidant which is a compound in the form of reduced glutathione (GSH) will decrease, so it is necessary to be given exogenous antioxidants. Therefore, this research is important to do to find the effectiveness of kersen leaves steeping [7,10-13]. Therefore, it is necessary to conduct research to test the effectiveness of steeping kersen leaves (Muntingia calabura L.) on changes in endogenous enzyme levels, namely the enzyme glutathione peroxidase (GPx).

\section{Material and Method}

\subsection{Ethical approval}

The animal handling and experimental procedure was conducted on the basis of authorization from the Medical and Health Science Ethics Committee, Medical and Health Science Faculty, Muhammadiyah Yogyakarta University (approval number: 420 / EP-FKIK-UMY / X/2016).

This research is an experimental study to test the effectiveness of steeping leaves of kersen (Muntingia calabura L.) on the level of GPx in diabetes mellitus rat induced by Streptozotocin-nicotinamide (STZ-Na) with post-test only with control category design. design. This research was conducted for 30 days using a white rat (Rattus norvegicus) Sprague Dawley strain. Criteria for inclusion of test animals used were Sprague Dawley strain male, \pm 8 weeks old, and weighing \pm 150 -200 grams. The rat whose activity was less / inactive, died during the treatment period, were sick (appearance of dull hair, loss, or bald), and experienced weight loss $>10 \%$ during the adaptation period in the laboratory were excluded from the study.

The independent variable was kersen leaves steeping (Muntingia calabura L.) with a dose of $250 \mathrm{mg} / \mathrm{Kg} \mathrm{BW}, 500 \mathrm{mg} / \mathrm{Kg} \mathrm{BW}, 750 \mathrm{mg} / \mathrm{Kg} \mathrm{BW}$, while the dependent variable was GPx enzyme levels. Associated with controlled variables are genetic factors, age, body weight, stable conditions and the same feed.

The materials used in this research were kersen leaves (Muntingia calabura L.) obtained from the yard in the PAU UGM nutrition laboratory, streptozotocin, metformin obtained in pharmacies, fasting blood plasma of mices, nicotinamide, $\mathrm{NaCl} 0.9 \%$, aqua, and rat liver tissue. The tools used in this research include digital scales to weigh rat, sonde to provide mice steeping, glass cups, syringes for taking blood glucose, gloves, masks, pots to boil 
water, filters, stoves, experimental animals, centrifuges, microcapillary tubes, spectrophotometers.

The second sample was taken 5 days after induction of Streptozotocin-nicotinamide with parameter levels of fasting blood glucose. Rats were declared diabetes mellitus if the fasting blood glucose level $>135 \mathrm{mg} / \mathrm{dl}[14,15]$. After the rats were declared diabetes mellitus, the rats were re-weighed to determine the treatment dose. Kersen leaves used are leaves that are dark green, not curly, and no insect bites. The leaves are taken from the laboratory yard of the food and nutrition center at Gadjah Mada University (UGM), dried in the sun to dry (brown), then brewed with boiling water until the color resembles tea, before being given to mice, steeping is filtered so that it is separated from the leaves.

The treatment was given according to each category for 14 days, the normal category was not given any treatment, the negative control category was only given aqua/rat/day, the positive control category was given metformin $0.9 \mathrm{mg} / 200 \mathrm{gr} \mathrm{BW} / \mathrm{rat} / \mathrm{day}$, the treatment category 1 ( P1) administered steers with $250 \mathrm{mg} / \mathrm{Kg} \mathrm{BW} / \mathrm{rat} /$ day dose, treatment category 2 (P2) administered with $500 \mathrm{mg} / \mathrm{Kg} \mathrm{BW} / \mathrm{rat} /$ day dose, and treatment category 3 (P3) administered with $750 \mathrm{mg} / \mathrm{Kg} \mathrm{BW} / \mathrm{rat} /$ day. After 14 days of treatment, rats were dissected to be taken and opened with GPx by comparing with GPx in the normal group.

\subsection{Data Analysis}

The data obtained were analyzed using paired-t-test for differences before and after induction and treatment, one way ANOVA test to determine the significance of differences between study categories, followed by post hoc-test and Tuckey average test.

\section{Results}

Research on the effectiveness of kersen leaves steeping (Muntingia calabura L) research has been carried out on Glutathione Peroxidase enzyme levels in Streptozotocin-Nicotinamideinduced Diabetes Mellitus rats. The whole category was declared diabetes mellitus rat with a fasting blood glucose level $>135 \mathrm{mg} / \mathrm{dl}$.

Table 1. Average levels of the enzyme GPx after treatment

\begin{tabular}{ccc}
\hline Groups & $\begin{array}{c}\text { Average GPx } \\
(\mathrm{U} / \mathrm{mg}) \pm \mathrm{SD}\end{array}$ & $p$ \\
\hline Normal & $73.96 \pm 1.53$ & \\
Negative Control & $11.44 \pm 0.69$ & 0.0001 \\
Positive Control & $68.70 \pm 0.47$ & \\
P1 (250 mg Kersen) & $28.68 \pm 0.46$ & \\
P2 (500 mg Kersen) & $44.11 \pm 0.67$ & \\
P3 (750 mg Kersen) & $66.70 \pm 0.83$ & \\
\hline
\end{tabular}

Table 1 show that the average among the treatment categories P1, P2, and P3 compared with the negative category average of $11.44 \mathrm{U} / \mathrm{mg}$ has increased. GPx levels in the treatment groups P1 (250 mg/Kg BW), P2 (500 mg/ Kg BW) and P3 (750 mg/Kg BW) had an increase compared to the negative control category and approached the positive and control categories.

The one-way ANOVA GPx enzyme test, the value of $p=0.0001(p<0.05)$ which means the average increase in GPx levels from the five different treatments. Tukey's post-hoc test results showed a statistically significant increase in GPx levels between the negative control 
group and P1, P2 and P3 $(p=0.01 ; p=0.001 ; p=0.001)$. The largest increase in GPx levels was in the $750 \mathrm{mg} / \mathrm{Kg} \mathrm{BW}$.

Table 2. Differences in GPx enzyme levels compared to the normal category

\begin{tabular}{ccc}
\hline Groups & $\begin{array}{c}\text { Average GPX } \\
\text { difference }(\mathrm{mg} / \mathrm{dl})\end{array}$ & $\mathrm{p}$ \\
\hline Negative Control & 62.51 & \\
Positive Control & 5.25 & 0.0001 \\
P1 & 45.28 & \\
P2 & 29.85 & \\
P3 & 7.26 & \\
\hline
\end{tabular}

Table 2 shows the difference in the levels of GPx enzymes in all treatment categories compared to the normal category where the smallest amount of difference was the positive control category followed by treatment P3 $(750 \mathrm{mg} / \mathrm{Kg}$ BB kersen leaves steeping). While the biggest difference was in the negative control followed by the P1 (250 mg/ Kg BW).

\section{Discussion}

Increased levels of Blood glucose are caused by the toxic effects of streptozotocin which can destroy pancreatic $\beta$ cells and liver tissue. Streptozotocin enters pancreatic $\beta$ cells through glucose transporter (GLUT2) and will cause DNA alkylation. Alkylation or the entry of methyl categories from streptozotocin into this DNA molecule will cause damage to DNA fragmentation. DNA damage will later activate poly adenosine diphosphate (ADP) ribosylation. This process will result in the elimination of cellular Nicotinamide adenine dinucleotide (NAD+), further there will be a reduction in adenosine triphosphate (ATP) and will ultimately inhibit insulin secretion and synthesis. Nicotinamide, which is a direct precursor of NAD + and as a ribose poly ADP inhibitor, will inhibit excessive DNA fragmentation damage which can cause hepatotoxicity so that mice will only become diabetes mellitus type $2[14,15]$.

GPx levels in the treatment groups P1 (250 mg/Kg BW), P2 (500 mg/Kg BW) and P3 $(750 \mathrm{mg} / \mathrm{Kg} \mathrm{BW}$ ) had an increase compared to the negative control group and approached the positive control. Research with the same results was also carried out by Aswani et al. (2015) entitled Potential Gotu Kola Extract (Centella Asiatica) and Turmeric (Curcuma longa) to increase the activity of the enzyme glutathione perksidase (GSH-Px) in rat liver tissue to get the results of Centella asiatica extract and Curcuma longa to increase the activity of the enzyme glutathione perksidase (GSH-Px) in rat liver tissue to obtain the results of the Centella asiatica extract and Centuria extract turmeric in normal liver, seen an increase in GSH-Px enzyme activity. The difference between this research and the research conducted by Aswani et al is the intervention used is curcuma longa and turmeric extract and the dosage varies between gotu kola and turmeric extract whereas in this study only used 3 doses namely $250 \mathrm{mg} / \mathrm{Kg} \mathrm{BW}, 500 \mathrm{mg} / \mathrm{Kg} \mathrm{BW}$, and $750 \mathrm{mg} / \mathrm{Kg}$ BW.The lowest decrease in GPx levels compared to the normal category is in the negative control category, it is due to oxidative stress that occurs in diabetes mellitus due to induction of Streptozotocin-nicotinamide [1618].

Hyperglycemia causes glucose auto-oxidation, protein glycation, and activation of polyol metabolic pathways which further accelerates the formation of reactive oxygen compounds. The formation of reactive oxygen compounds can increase lipid, DNA, and protein modification in various tissues. Molecular modification in various tissues results in an imbalance between protective antioxidants (antioxidant defenses) such as antioxidant 
enzymes such as SOD, GPx, and catalase and increased production of free radicals. That is the beginning of oxidative damage known as oxidative stress [19-21].

The distribution of kersen leaf extract on white mice (Muntingia calabura L.) seems to show an increase in GPx levels. It can be seen in Table 4 that in the treatment group P1 (250 $\mathrm{mg} / \mathrm{Kg} \mathrm{BW}), \mathrm{P} 2(500 \mathrm{mg} / \mathrm{Kg} \mathrm{BW})$ and P3 (750 mg/Kg BW) experienced an increase compared to the negative category. Flavonoids in kersen are able to play a role in capturing free radicals or function as natural antioxidants. Research in animal studies proves that antioxidants can inhibit the early stages of retinopathy, nephropathy, and neuropathy. These antioxidant activities allow flavonoids to capture or neutralize free radicals (such as ROS or RNS) associated with phenolic groups so that the imbalance between protective antioxidants such as the GPx enzyme can be increased [10,21].

This studi showed that increasing GPx levels after being treated with kersen leaves. The most effective dose for increasing the GPx level was $750 \mathrm{mg} / \mathrm{Kg} \mathrm{BW}$.

\section{Conclusion}

Kersen leaves steeping is effective in increasing levels of the GPx enzyme in diabetic rats.

\section{References}

1. Animaw W, Seyoum Y. Increasing prevalence of diabetes mellitus in a developing country and its related factors. PlosOne, 10:1371 (2017).

2. Ministry of Health of the Republic of Indonesia. Indonesia Health Profile 2018. Jakarta (2018).

3. Chen L, Magliano DJ, Zimmet PZ. The worldwide epidemiology of type 2 diabetes mellituspresent and future perspectives. Nat Rev Endocrinol., 8(4):228-36 (2011).

4. WuY, Ying Y, Tanaka Y, Yang W. RiskFactorsContributingto Type2Diabetes andRecent Advances in the Treatment and Prevention. Int J Med Sci., 11(11):1185-200 (2014).

5. Jung UJ, Choi MS. Obesity and Its Metabolic Complications: The Role of Adipokines and the Relationship between Obesity, Inflammation, Insulin Resistance, Dyslipidemia and Nonalcoholic Fatty Liver Disease. Int J Mol Sci. 15(4):6184-223 (2014).

6. Yamada S. Paradigm Shifts in Nutrition Therapy for Type2 Diabetes. Keio J Med. 26;66( 3):33-(2017).

7. Oikonomou D, Groener JB, Cheko R, Kender Z, Kihm L, Fleming T, Kopf S, Nawroth PP.Genetic Polymorphisms of Antioxidant and Antiglycation Enzymes and Diabetic Complications. How Much Can we Learn from the Genes? Exp Clin Endocrinol Diabetes. 126(1):7-13 (2018).

8. Ueno, Y., Kizaki, M., Nakagiri, R., Kamiya, T., Sumi, H., \& Osawa, T. Dietary gluthatione protects rats from diabetic nephropathy and neuropathy. J Nutr;132:897-900 (2002).

9. Hebi M, Eddouks M.Hypolipidemic and Antioxidant Activities of Corrigiola telephiifolia in Diabetic Rats. Cardiovasc Hematol Agents Med Chem. 17(1):47-51 (2019).

10. Indriawati $\mathrm{R}$, The hepatoprotective capacity of steeping kersen leaves (Muntingia calabura L.) on diabetic rat. Electronic Journal of General Medicine. 17(5): em225 (2020)

11. Lim, T.K. Edible Medicinal and Non-Medicinal Plant. London New York. Springer Dordrecht Heidelberg. Hal : 489-91 (2012).

12. Indriawati R, Rose LP, Ulfa SM. The effect of giving lidah buaya (aloe vera) juice to decrease amount of blood glucose and triglycerides in rattus norvegicus induced by alloxan. MajalahIlmu Faal Indonesia,9(2) (2010). 
13. IndriawatiR. The effect of rosellared tea steeping(hibiscus sabdariffa l) on fasting glucose level, two hours post prandial and blood triglycerides. Majalah Ilmu Faal Indonesia. 10(2):107-12 (2013).

14. Szkudelski T. The Mechanism of Alloxan and StreptozotocinActionin BCellsofRatPancreas. Physiol. 50:536-46 (2001).

15. Szkudelski T. Steptozotocin-nicotinamide-induced diabetes in rat characteristics of the experimentalmodel. Exp. Biol. Med. 5(237):481-90 (2012).

16. Aswani, T., Manalu, W., Suprayogi, A., \& Rahminiwati, M. Potential of Gotu Kola (Centella Asiatica) and Turmeric (Curcuma longa) Extracts To Increase Glutathione Perksidase (GSH-Px) Enzyme Activity in Rat Liver Tissue. Jurnal Ilmu-ilmu Hayati. (2015).

17. Bayrasheva VK, Yu A, Dobronravov VA, Dmitriev YV, Chefu SG, Pchelin IY, Grineva EN. Uninephrectomized High-Fat- Fed Nicotinamide-Streptozotocin-Induced Diabetic Rats: A Model for the Investigation of Diabetic Nephropathy in Type 2 Diabetes. J Diabetes Res. 83:17-50 (2016).

18. Nagarajan S, Manonmani AJ, Duraiswami S, Balasubramanian NK. Effect of Sylmarin on streptozotocin- nicotinamide-Induced Type 2 Diabetic Nephropathy in Rats. Department of pharmacology Swamy Vivekanandha College of Pharmacy, Elayampalayam Tiruchengode, Tamil Nadu, India. IJKD. 117 (2013).

19. Ghasemi A. Streptozotocin-nicotinamide induced rat model of type 2 diabetes. Impact Factor: A physiol. 101:2(2014).

20. Finivera V. Indriawati R. Effectiveness of Red Roselle Tea (Hibiscus Sabdariffa L.) Giving Against HDL and LDL Levels in Aloxan-Induced Rattus Norvegicus. Thesis. Universitas Muhammadiyah Yogyakarta. (2011).

21. Antioxidants Attenuate Oxidative Stress-Induced Hidden Blood Loss in Rats. Qian H, Yuan T, Tong J, Sun WS, Jin J, Chen WX, Meng J, Bao N, Zhao J. Turk J Haematol. 1;34(4):334-339 (2017).

22. Botutihe. Effects of Brown Seaweed Extract (Sargassum duplicatum Bory) on the Free Radical Profile and Protein of Kin Lung (Rattus Novergicus) Exposed (A) Piren,Tesis. Universitas Brawijaya. Malang. (2010).

23. Aswani, T., Manalu, W., Suprayogi, A., \& Rahminiwati, M. Potential of Gotu Kola (Centella Asiatica) and Turmeric (Curcuma longa) Extracts To Increase Glutathione Perksidase (GSH-Px) Enzyme Activity in Rat Liver Tissue. Jurnal Ilmu-ilmu Hayati. (2015).

24. Szkudelski, T. (Streptozotocin-nicotinamide-induced diabetes in the rat. Characteristics of the experimental model. Experimental Biology and Medicine. 481-490 (2012).

25. Eleazu, C.O, Eleazu, K.C., Chukwuma, S., Essien, N.U., (2013) Review of the mechanism of cell death resulting from streptozotocin challenge in experimental animals, its practical use and potential risk to humans.Journal of Diabetes \& Metabolic Disorders. 12:60 (2013). 